\title{
Antonio Panizzi og Det kgl. Bibliotek
}

\author{
Det kgl. Bibliotek som eksempel i engelsk \\ biblioteksdebat i første halvdel af 1800-tallet
}

Af Svend Larsen

Titlen kunne antyde, at der var en særlig relation mellem Antonio Panizzi og Det kgl. Bibliotek i København. Det er ikke tilfældet, men Panizzi har indhentet oplysninger om Det kgl. Bibliotek og brugt dem i sin kamp for bedre forhold for "sit eget « bibliotek, British Museum Library. Panizzis oplysninger om Det kgl. Bibliotek indgår sammen med oplysninger om andre europæiske biblioteker i en rapport fra det udvalg i det britiske parlament, der i 1836 behandlede British Museum's forhold. På grundlag af dette materiale kan man give et bidrag til at placere Det kgl. Bibliotek i europæisk sammenhæng i første halvdel af 1800-tallet. Panizzis sammenligning af europæiske biblioteker og den brug, han gør af den, giver endvidere et historisk perspektiv på det stadig aktuelle spørgsmål om, hvad der er et nationalbiblioteks opgaver. Endelig er det formålet at pege på et omfattende kildemateriale om europæiske biblioteksforhold, som ikke er meget benyttet uden for engelsk bibliotekshistorie.

\section{Ambassadeindberetningen 1835}

I 1835 nedsatte det britiske parlament et udvalg til at undersøge forholdene ved British Museum. Den direkte anledning til, at udvalget blev nedsat, var fyringen af en medarbejder ved museets bibliotek, en sag som blev taget op af et nyt parlamentsmedlem. Men baggrunden var længere tids kritik, som karakteriserede speci- 
elt bibliotekets forhold som utidssvarende. ${ }^{1}$ Parlamentsudvalget behandlede ud over fyringssagen (som viste sig velbegrundet) en række forhold i bl.a. museets zoologiske afdeling. Den afsluttende indstilling fra udvalget indeholder blot en opfordring til, at der i næste parlamentssamling nedsættes et nyt udvalg.

Udvalgsrapporten er imidlertid en stor sag (622 sider), idet udvalget offentliggør et omfattende materiale om museets økonomiske forhold samt om biblioteker og museer i en række europæiske lande. Oplysningerne om de europæiske biblioteker og museer var indsamlet af de engelske ambassadører på foranledning af udenrigsministeriet, der rundsendte en række spørgsmål fra det nævnte parlamentsmedlem. Oplysningerne om biblioteker og museer i Bayern, Frankrig, Preussen, Rusland og Spanien er ret omfattende, men ellers er der tale om korte oversigter. For Københavns vedkommende er der et skema med oplysninger om de tre største biblioteker (Det kgl. Bibliotek/King's Library, Universitetsbiblioteket og Det Classenske Bibliotek) og et skema med oplysninger om museerne. ${ }^{2}$ De spørgsmål, ambassadørerne har indhentet svar på, er ret elementære. Hvor mange biblioteker er der, hvor mange ansatte, antal bind, samlede udgifter og lignende? Materialet blev da også kun benyttet i begrænset omfang i udvalgets forhandlinger. Anderledes skulle det gå med det materiale, Antonio Panizzi forelagde for parlamentsudvalget i 1836 .

\section{Panizzi og 1836-undersøgelsen}

Parlamentet nedsatte i 1836 et nyt udvalg til at undersøge forholdene ved British Museum. Panizzi blev indkaldt som vidne og forelagde i den forbindelse oplysninger om en række udenlandske biblioteker. ${ }^{3}$ I 1836 var Antonio Panizzi assistent i British Museum's Department of Printed Books, hvor han var blevet ansat i 1831. Panizzi har i en senere beretning fortalt om baggrunden for indsamlingen af information om biblioteker på det europæiske fastland.

Allerede i 1833 fornemmede Panizzi og hans chef, Henry Baber, Keeper of Printed Books, at parlamentet ville se nærmere på forholdene ved British Museum, og de mente, at det ville gavne institutionen, hvis man kunne fremlægge oplysninger om andre landes 
biblioteksvæsen. ${ }^{4}$ Panizzi opstillede derfor en række spørgsmål, som blev sendt til en række europæiske biblioteker, deriblandt Det kgl. Bibliotek i København. ${ }^{5}$ Derudover besøgte Panizzi i 1835 flere biblioteker i Belgien, Frankrig og Tyskland.

Der var altså tale om grundig forberedelse, og Panizzis strategi bag sammenligningen med andre biblioteker er klar: sammenligningen skal vise, at British Museum Library er et godt bibliotek, i flere henseender det bedste, men der er mangler, og disse mangler skyldes først og fremmest, at der ikke ofres penge i et omfang, der er den britiske nation værdig.

\section{Panizzis sporgsmål}

Panizzi fik svar på sine spørgsmål fra 27 biblioteker, heraf 4 i Firenze, 5 i Paris og 7 tyske (dog ikke fra München, hvad Panizzi beklager). For Danmarks vedkommende sendte han spørgsmålene til Det kgl. Bibliotek, men han er klar over, at der findes andre biblioteker i København. ${ }^{6}$

Bibliotekerne blev bedt om at besvare i alt 20 spørgsmål. Spørgsmålene er koncentreret om bestand, bogkøbsbevilling og benyttelse. Hvad angår bestand, anfører Panizzi for Det kgl. Bibliotek 400.000 bind, hvortil kommer 15.000 manuskripter og 77.000 stik. Målt i bindtal er Det kgl. Bibliotek Europas tredjestørste, kun overgået af det kongelige bibliotek i Paris og hof- og statsbiblioteket i München. ${ }^{7}$ Efter Det kgl. Bibliotek i København kommer bibliotekerne i Berlin, Wien og Dresden og først derefter British Museum Library med 240.000 bind. $^{8}$

Hvad angår bogkobsbevilling, angives Det kgl. Bibliotek at have en årlig bevilling svarende til 450 pund sterling. Den årlige tilvækst er på ca. 3.000 bind. ${ }^{9}$ I Det kgl. Bibliotek syntes man selv, at det var for lidt, og helt utilstrækkeligt til, at man kunne holde positionen som Nordeuropas største bibliotek. ${ }^{10}$ Men sammenlignet med andre ligger Det kgl. Bibliotek ikke så dårligt. Bedre stillet er kun bibliotekerne i Berlin, Göttingen, Paris og Wien, som alle har mere end 1000 pund om året til bogkøb, og British Museum Library, der har knap 1000 pund om året.

Ser man herefter på adgangen til bibliotekerne og benyttelsen, er Det 
kgl. Bibliotek ikke længere højt placeret på Panizzis rangliste. I en kommentar til spørgsmålet om bibliotekernes officielle navne gør Panizzi opmærksom på, at bibliotekerne i Berlin, Dresden og København tilhører kronen, og at offentlighedens adgang til disse biblioteker ikke er en ret, men et udtryk for monarkens velvilje. ${ }^{11}$ Ganske vist er Det kgl. Bibliotek et af de fầ biblioteker, hvor der ikke er begrænsninger for, hvilke bøger man kan benytte i bibliotekets læsesal. Andre steder, f.eks. Göttingen, er personalet berettiget til (af moralske grunde) at nægte lån af visse bøger til visse lånere, og $\mathrm{i}$ de katolske lande er der bøger, som er forbudte. Men Det kgl. Bibliotek er et af de fă biblioteker i Panizzis undersøgelser, hvor der ikke er helt fri adgang til biblioteket. I København skal man ligesom i Berlin godkendes af personalet for at benytte biblioteket, mens der i f.eks. Dresden, Göttingen, München og Paris er helt fri adgang til at benytte læsesalen. ${ }^{12}$

Hvad angår kataloger, er situationen ikke bedre set med Panizzis øjne. Han spørger først, om alle bøger er katalogiserede, om der både er alfabetisk og systematisk katalog, og om katalogerne er trykte. For Det kgl. Bibliotek er svaret, at alle udenlandske bøger er katalogiseret, men at hverken den systematiske katalog i 199 bind eller den alfabetiske seddelkatalog er trykt. ${ }^{13}$ På det punkt ligner Det kgl. Bibliotek andre store biblioteker. Det gælder også for det næste spørgsmål, som er vigtigt for Panizzi. Spørgsmålet lyder: er katalogerne tilgængelige for lånerne som en selvfølgelighed, og er de altid inden for rækkevidde, eller skal lånerne bede om tilladelse til at benytte dem? Det kan godt være, at kravet om tilladelse er en ren formssag, men for Panizzi er det afgørende retten til fri adgang til katalogerne. Og hvad det angår, falder de store biblioteker på kontinentet igennem. I Berlin, Göttingen, München, Paris og Wien kan lånerne i varierende omfang fẳ lov at bruge katalogerne, men det er ikke en ret, de har. Det samme gælder for Det kgl. Bibliotek, hvor adgangen til at bruge katalogerne angives at være helt afhængig af overbibliotekarens vilje. ${ }^{14}$

Også med andre spørgsmål fokuserer Panizzi på offentlighedens muligheder for at benytte bibliotekerne. Han stiller spørgsmål om daglig åbningstid og om, hvor mange dage om året bibliotekerne er 
åbne. Det kgl. Bibliotek har med sine 3 timer kortere åbningstid end de kongelige biblioteker i Berlin og Paris med 5 timers daglig adgang, men ligger pænt, hvad angår det antal dage pr. år, hvor der er lukket. I Berlin er der lukket 70 dage om året, i København 94 dage, i Paris 115 dage. Rekorden har det kongelige bibliotek i Haag med 216 dage uden adgang! $!^{15}$

Der er også spørgsmål om den faktiske benyttelse, idet Panizzi beder om at fầ oplyst det årlige antal registrerede lånere og det daglige antal lånere i læsesalen og arten af de bøger, de bruger. Det kgl. Bibliotek oplyser ikke antal registrerede lånere, men anfører at der ikke er begrænsninger i henseende til køn og alder. Det daglige antal lånere angives til 5-8, og de bruger først og fremmest videnskabelige værker. ${ }^{16}$ Det kgl. Biblioteks oplysninger videregives uden kommentarer, mens Panizzi tydeligvis ikke tror på nogle af andre bibliotekers oplysninger. Det kongelige bibliotek i Paris opgiver et dagligt lånertal på mellem 300 og 500, men Panizzi har under sine besøg der aldrig set flere end 57! Göttingen opgiver et tal på mellem 20 og 30, men i de to dage, Panizzi var der, så han ikke en eneste, hvilket dog ifølge Panizzi kunne skyldes den stærke kulde netop de dage!

Panizzi stiller også spørgsmål om udlån fra samlingerne. Panizzis holdning fremgår af spørgsmålets formulering, idet han beder om at fă belyst ulemperne ved denne praksis. Som andre store biblioteker, f.eks. i Berlin, Dresden, München og Paris, tillader også Det $\mathrm{kgl}$. Bibliotek udlån. Enhver respektabel person kan hjemlåne fra Det kgl. Bibliotek. Lånetiden er 14 dage. Normalt udlånes kun 2 bind ad gangen, men professorer og andre lærde kan låne op til 30 eller 40 bind ad gangen. Det årlige udlånstal er 3000-4000 bind. Der angives at være mange ulemper ved denne praksis, fordi bøgerne på denne måde ikke er alment tilgængelige, eller de forsvinder ligefrem. Men, hedder det, "kongen vil hellere finde sig i disse ulemper end begrænse brugen af sin samling «! ${ }^{17}$ Spørgsmålet om hjemlån var sammen med spørgsmålet om udformningen af kataloger de centrale spørgsmål i den europæiske biblioteksverden i første halvdel af 1800-tallet, og ikke mindst i England var diskussionen intens, hvilket dokumenteres i rigt mål i referaterne af forhandlingerne i de 
parlamentsudvalg, der i 1836 og senere fik til opgave at undersøge forholdene ved British Museum Library.

Panizzis brug af oplysningerne om europaiske biblioteker

Som nævnt havde Panizzi en klar hensigt med sin sammenligning af europæiske biblioteker. Det fremgår af hans vidneudsagn for parlamentsudvalget. Han tegner billedet af en institution, der er værd at satse på. Tallene viser, at British Museum Library ikke er blandt de 6 største. Men bindtal er ikke alt! Ser man på indholdet af samlingerne, er sagen en anden. Hvad angår sjældenheder og moderne kostbare værker kan museumsbiblioteket sagtens stå sig i en sammenligning. Det er et værdifuldt bibliotek, med meget få overflødige bøger. ${ }^{18} \mathrm{Og}$ hvad angår kataloger, er biblioteket simpelthen enestående, for kun i British Museum's bibliotek har lånerne ret til at benytte katalogerne, og de har let adgang til dem. I bibliotekerne på kontinentet har lånerne ikke denne ret, men kan kun bruge katalogerne, hvis det passer personalet. ${ }^{19}$

Panizzi er godt klar over, at katalogerne i hans eget bibliotek lader noget tilbage at ønske, og at de formelt set ikke er så udbyggede som andre steder. Men han mente på det tidspunkt, at den sag var $\mathrm{i}$ god gænge. ${ }^{20}$ Der kan i hvert fald ikke hentes inspiration $i$ andre biblioteker. Ingen steder har man tilfredsstillende kataloger, heller ikke i biblioteket i Göttingen, hvis kataloger jo ellers havde været forbilledet mange steder, bl.a. i København. Katalogen i Göttingen er nok den bedste af eksisterende kataloger, men ikke god nok! ${ }^{21}$

Sammenlignet med andre er det britiske bibliotek altså ikke bagud. Men der er nok at tage fat på, og det kræver penge. Det er Panizzis budskab til parlamentsudvalget. Panizzi gør opmærksom på, at mens det $i$ andre lande er det offentlige, der finansierer bibliotekerne, er størstedelen af museumsbibliotekets værdifulde samlinger kommet til veje ved gaver. Kun en tredjedel af bibliotekets kapital i form af bøger stammer fra penge bevilget af nationen. Det er ikke en tilstand, der værdig for den britiske nation, og kun en tidobling af bogkøbsbevillingen kan ændre på det. ${ }^{22}$ British Museum skal være et nationalt forskningsbibliotek, og skal derfor satse på at samle sjældne, specielle og store, dyre værker. Det er bøger, som 
ikke kan findes andre steder, og som videnskabsmænd med rette kan forvente stillet til deres rådighed af landets regering. Adgang til sådanne bøger bør være lige for alle, siger Panizzi med ord, der ofte er blevet citeret: "Jeg ønsker, at en fattig student skal have samme mulighed, hvad angår bøger, for at tilfredsstille sin intellektuelle nysgerrighed, forfølge sine åndelige interesser, have adgang til de samme kilder og komme til bunds i de mest komplicerede spørgsmål som den rigeste mand $\mathrm{i}$ kongeriget, og jeg vil påstå, at regeringen er forpligtet til at give ham så fordomsfri og ubegrænset hjælp som muligt til dette. ${ }^{23}$

Panizzi formulerer her det ideal om et nationalbibliotek, der var ledetråden i hans senere virke. Han peger på kulturnationens pligt til at give tilstrækkelige midler til en national institution, hvis formål er at fremme uddannelse og forskning, og han peger på alles lige ret til at benytte denne institution.

Ved samme lejlighed slår Panizzi fast, at det at drive et stort, tidssvarende bibliotek er en sag for professionelle biblioteksfolk. Det kan ikke overlades til interesserede amatører eller til videnskabsmænd. Det gør han meget klart, hvor han taler om katalogisering og om styrelsesforholdene ved British Museum. Mange har udtalt sig om katalogisering, som om det var noget, alle kunne. Men det kræver en kombination af intellektuelle og faglige kundskaber. Det er ingen enkel sag. Det kan tage en dag eller mere at katalogisere en bog, sådan som det bør gøres i et nationalbibliotek! ${ }^{24}$ Hvad angår videnskabsmænd, bør de ikke have særlig indflydelse på bibliotekets drift. Panizzis erfaring med videnskabsmænd er, at de er dogmatiske og snæversynede. De tror sig ufejlbarlige og vil derfor ikke spørge professionelle biblioteksfolk til råds. At give videnskabsmænd en central placering i bestyrelsen for British Museum vil efter Panizzis mening på ingen måde fremme den faglige udvikling. ${ }^{25}$

Året efter at Panizzi fremkom med disse markante udtalelser, fik han bedre mulighed for at realisere sine ideer. Han blev i 1837 udpeget til leder af det, der var kernen i museumsbiblioteket, Department of Printed Books. 


\section{Udlånssporgsmålet}

I Panizzis første tid som Keeper of Printed Books skete der en del ændringer. Biblioteket blev flyttet til nye og større lokaler, og bogkøbsbevillingen blev forøget. Af mindre, men stærkt omdiskuterede ændringer kan nævnes indførelsen af skriftlig rekvisition af bøger. Hidtil havde lånere blot skullet bede personalet om en bog. $\mathrm{Nu}$ blev det obligatorisk at benytte lånesedler, og det er måske det eneste punkt, hvor Panizzi bevidst følger andre store biblioteker. Et af Panizzis spørgsmål handlede om dette, og af svarene fremgår det, at skriftlig rekvisition bruges i København, Berlin, München og Paris. ${ }^{26}$

På et punkt skete der ingen ændring, nemlig hvad angår udlån. Panizzi ønsker, at British Museum Library skal være et nationalt forskningsbibliotek åbent for de mange, der har brug for en sådan institution. Men biblioteket skal ikke være et "uddannelsesbibliotek " med udlån af nye bøger som f.eks. universitetsbiblioteket $\mathrm{i}$ Göttingen. Der er tale om to helt forskellige bibliotekstyper, som bør drives efter vidt forskellige principper. Der er nok behov for et uddannelses-(universitets-)bibliotek i London, men det er ikke British Museum Library, der skal tage sig af den opgave. ${ }^{27}$

Ønsket om at kunne hjemlåne bøger var imidlertid stort, og da der ikke skete noget fra officielt hold, tog en gruppe privatpersoner et initiativ, der førte til oprettelsen af det stadig eksisterende London Library. Det blev oprettet i 1841 som udlånsbibliotek for medlemmer. Den egentlige ophavsmand var den berømte forfatter og historiker Thomas Carlyle, der var meget utilfreds med forholdene ved museumsbiblioteket og i øvrigt en indædt kritiker af Antonio Panizzi. Carlyle inspirerede en ung jurist, W. D. Christie, til at skrive en slags manifest for London-biblioteket. Heri fremhæves den danske konges oplyste holdning til udlån af bøger, idet der henvises til det københavnske udsagn om, at kongen hellere finder sig i ulemperne ved udlån end indskrænker brugen af sin samling. ${ }^{28}$ Hvor Panizzi lægger vægt på den nationale samling og dens integritet, er det afgørende for andre den liberale udlånspraksis, uanset om den er en kongelig gunstbevisning. ${ }^{29}$ Med til historien hører dog, at man i København ikke var ubetinget tilfreds med hjemlånspraksis. Man 
kendte både til uefterrettelige lånere og til røster, der talte for begrænsning af udlånet. ${ }^{30}$

Udlånsspørgsmålet var imidlertid ikke det eneste, der optog den londonske biblioteksverden. Også katalogspørgsmålet blev kraftigt debatteret, og diskussionen blev præget af voldsomme personlige modsætninger i British Museum. Resultatet blev, at der i $1847 \mathrm{blev}$ nedsat en kongelig kommission til endnu en gang at undersøge forholdene ved museet. Kommissionen afgav betænkning i 1850 . Samme år vedtog parlamentet den første lov om offentlige biblioteker. I arbejdet med at forberede denne lov indgik et omfattende statistisk materiale, hvori københavnske biblioteksforhold har en flot placering. Dette statistiske materiale var for størstedelens vedkommende samlet af Edward Edwards. Materialet blev kraftigt kritiseret både i kommissionen om British Museum og i parlamentsudvalget om offentlige biblioteker. Den stærkeste kritiker var Antonio Panizzi.

\section{Edward Edwards' biblioteksstatistik}

Edward Edwards betragtes sammen med politikeren William Ewart som grundlægger af de engelske folkebiblioteker. Edwards, selvlært søn af en murer, var hele sit liv optaget af folkeoplysning og bibliotekernes bidrag hertil. I 1836 udgav den da 24-årige Edwards en pamflet, hvor han argumenterede for udvidede åbningstider, flere bøger og bedre kataloger i British Museum Library. Edwards uddybede sine betragtninger i sit vidneudsagn for parlamentsudvalget om British Museum. ${ }^{31}$ I 1839 blev Edwards ansat i museumsbiblioteket som assistent under Panizzi. Det varede ikke længe, før de to ragede uklar. Edwards var mere optaget af de store linjer end af det, han var ansat til, nemlig at katalogisere.

I sin kamp for bibliotekssagen kastede Edwards sig over biblioteksstatistikken. Han indsamlede oplysninger om forholdene $i$ andre lande og kunne på den måde dokumentere, hvor dårligt Storbri-

Side 30-31:

Edward Edwards' Europakort med bibliotekernes bindtal sat $i$ forhold til indbyggertal. Fra Report from the Select Committee etc., 1849. 


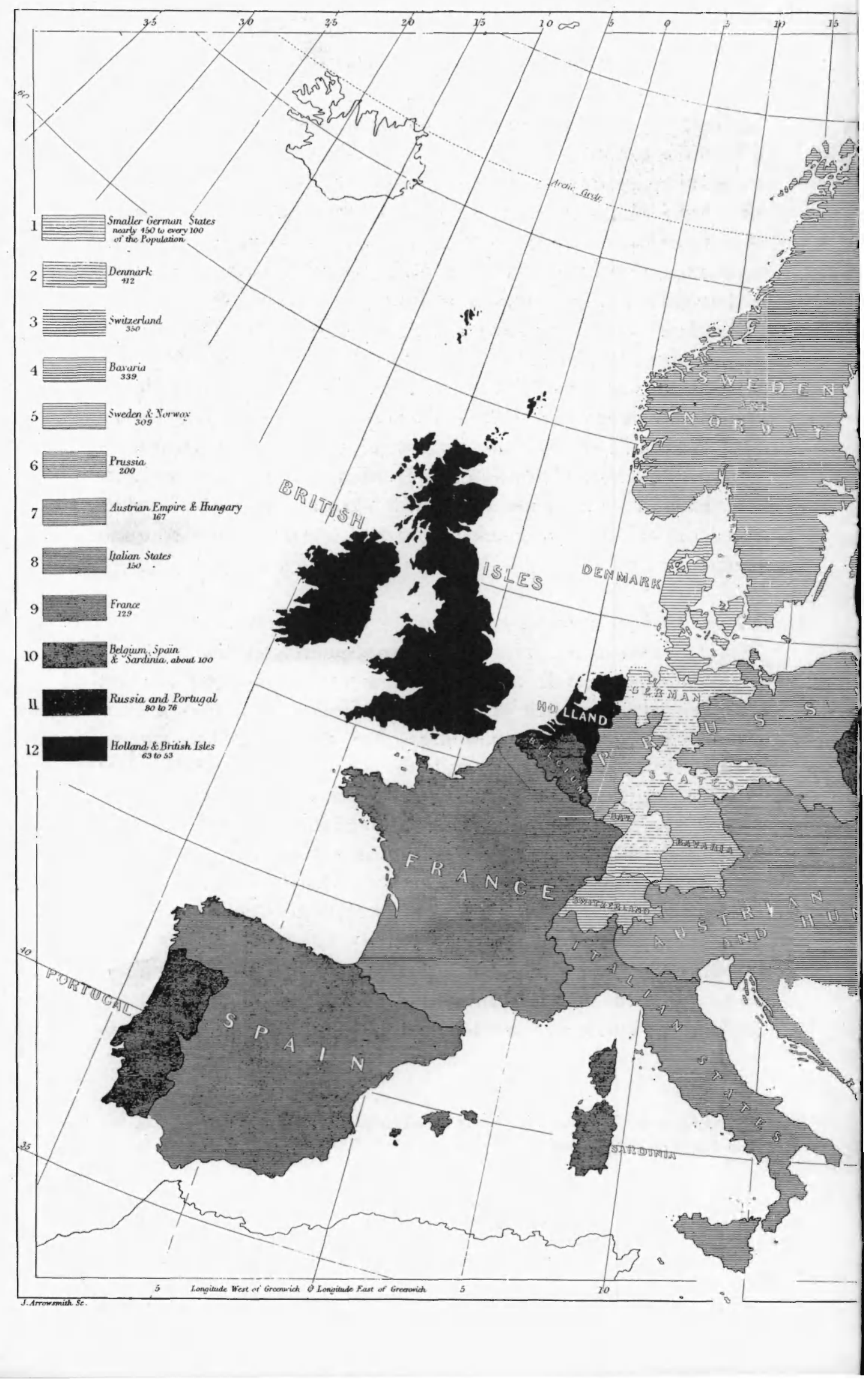




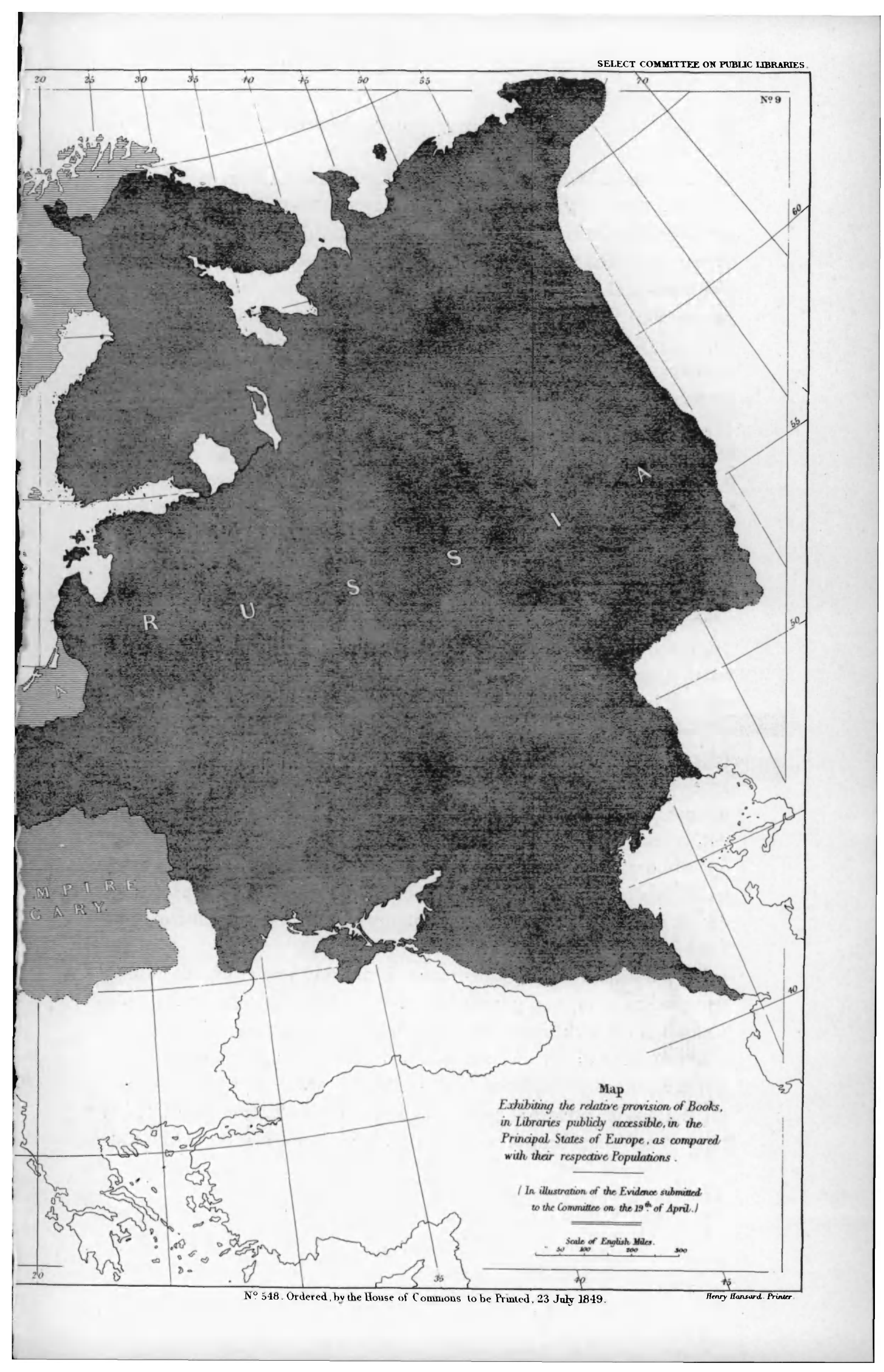


tannien var forsynet med offentlige biblioteker i forhold til andre lande. I 1848 offentliggjorde Edwards "A Statistical view of the principal Public Libraries in Europe and the United States of North America". Med visse tilføjelser (og ændring af titlen til Approximative statistical view!) forelagde Edwards i 1849 sit materiale for parlamentsudvalget om offentlige biblioteker. ${ }^{32}$ I tabellerne indtager Det kgl. Bibliotek i København med 412.000 bind pladsen som det femtestørste bibliotek efter bibliotekerne i Paris, München, Skt. Petersborg og London, mens Universitetsbiblioteket i København er placeret som nummer 12 blandt universitetsbibliotekerne. Oplysningerne om de danske biblioteker angiver Edwards selv at have fra L. A. Constantin (Hesse): Essai d'une statistique des bibliothèques publiques des pays étrangers de l'Europe (Paris 1841). Det interessante er da også Edwards' fremlæggelse af materialet for parlamentsudvalget. For de store europæiske "biblioteksbyer", heriblandt København, kan Edwards fremvise grundrids med angivelse af bibliotekernes placering, men det mest virkningsfulde er nok Europakortet med angivelse af bogforsyningen i de enkelte lande. Kortet viser, at Danmark er godt forsynet med offentlige biblioteker, mens Storbritannien er lavt placeret.

I sit vidneudsagn for udvalget fremhæver Edwards, at bibliotekerne på kontinentet i realiteten har fri adgang, og at de er udlånsbiblioteker. ${ }^{33}$ Han mener, at også British Museum Library burde udlåne bøger. Det er også et stort nationalbiblioteks opgave at stille den nyeste litteratur til rådighed, selv om den kan lånes billigt $\mathrm{i}$ et lejebibliotek. ${ }^{34}$ Han er i det hele taget kritisk over for museumsbibliotekets service. Man gør ikke nok for at skaffe den nyeste litteratur og gøre den tilgængelig, og katalogerne er ikke ajourførte, hvilket begrænser brugen.

Da parlamentsudvalget fortsatte sit arbejde året efter, fik Panizzi lejlighed til at tage til genmæle. Han ville ikke høre tale om kritik, og han betragtede Edwards som en illoyal uromager. Panizzi forholdt sig ikke til det, der var Edwards' overordnede mål, nemlig at fă flere offentlige biblioteker, specielt $\mathrm{i}$ de større byer. Tværtimod gik han løs på Edwards' person og søgte at miskreditere ham ved at så tvivl om hans biblioteksstatistik. Panizzi stod bag en række ind- 
læg mod Edwards $\mathrm{i}$ aviser og tog selv fat $\mathrm{i}$ sit vidneudsagn for udvalget. ${ }^{35}$ Panizzi fremhæver, at han har besøgt ikke mindre end 95 biblioteker og selv har beskæftiget sig med statistik, bl.a. i forbindelse med undersøgelsen i 1836. På den baggrund slår han fast, dels at Edwards' statistik er fuld af fejl i talangivelserne og derfor ubrugelig, dels at man i British Museum Library ikke kan lære noget af andre biblioteker! ${ }^{36}$ Panizzi mener, at Edwards overvurderer den frie adgang til bibliotekerne på kontinentet, og at museumsbiblioteket klart overgår andre, hvad angår faciliteter som adgang til kataloger og ekspeditionstid. Han kritiserer også, at Edwards i sin indsamling af materiale har foregivet, at han handlede på vegne af British Museum. Edwards' svar på kritikken var afdæmpet. Han indrømmer, at der er fejl i materialet, og siger, at det ikke kan være anderledes, idet det er et første forsøg på at lave en sammenlignende biblioteksstatistik. Men selv om han har placeret et spansk bibliotek i Portugal og andet af den slags, giver undersøgelsen et indtryk af landenes indbyrdes placering, hvad angår biblioteksforhold. Heri ligger undersøgelsens værdi, uanset at der i sagens natur ikke kan være tale om absolut nøjagtighed. ${ }^{37}$

Panizzi fremhæues ofte som den, der hævder princippet om lige adgang til biblioteker. Rigtigt er det, at han kraftigt forfægter princippet om, at alle lånere skal behandles ens. ${ }^{38}$ Men for en forståelse af Panizzis bibliotekssyn er det interessant at se, hvor mange forbehold han har over for Edwards' ide om åbne biblioteker, hvor man også kan finde de nyeste bøger. Ifølge Panizzi er fri adgang til biblioteker en betænkelig sag i de store byer; der er lommetyve, og der er hensynet til de kvindelige lånere. De nyeste bøger hører ikke hjemme i et forskningsbibliotek, for det er ikke de seriøse forskere, der benytter dem, og i et rigtigt forskningsbibliotek kan der ikke blive tale om udlån, for svind og ødelæggelse af bøger er en uundgåelig følge. ${ }^{39}$

Forklaringen på disse forbehold, som umiddelbart virker overraskende, er måske den enkle, at Panizzi var mere optaget af at forsvare sit eget bibliotek end af generelle principper. Da han udtalte sig til parlamentsudvalget om offentlige biblioteker, havde han de 


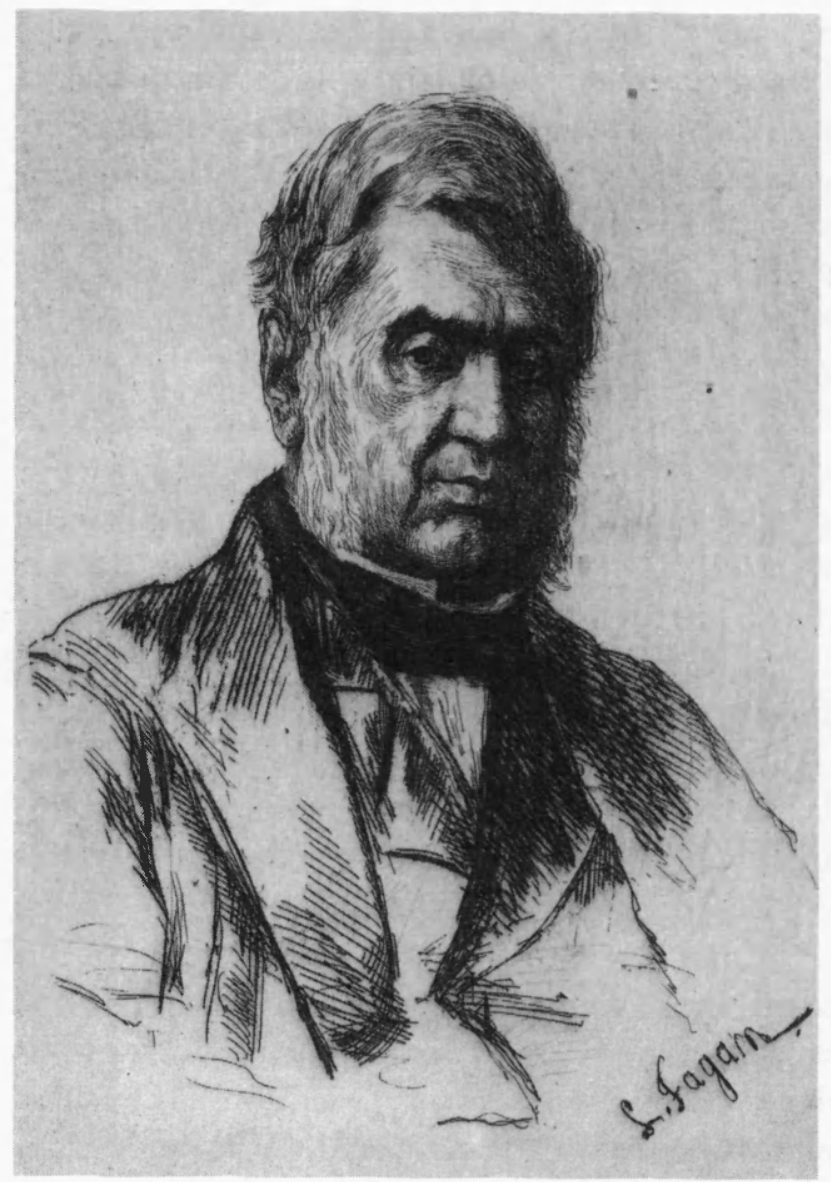

Antonio Panizzi, 69 år gammel.

Tegning af Louis

Fagan 1866. Fra

Fagan: The Life

of Sir Anthony

Panizzi. London

1880.

foregående år måttet optræde som vidne 18 gange for den kongelige kommission om British Museum! Forhandlingerne i kommissionen kom i stor udstrækning til at dreje sig om museumsbibliotekets kataloger, og kommissionsbetænkningen er en mageløs kilde for den, der interesserer sig for katalogiseringens væsen og katalogisatorers psykologi. ${ }^{40}$ Men som Panizzis første biograf anfører, blev den kongelige kommission det forum, hvor Panizzi konfronteredes med det ideal om et nationalbibliotek, han selv havde formuleret. ${ }^{41}$

Hans mål var at skabe det bedste nationalbibliotek i verden med de største og mest repræsentative samlinger, som skulle være let 
tilgængelige. Panizzi påstår ikke, at målet er nået, men han fremhæver, at han har besøgt de største biblioteker i Europa, undtagen det i København, og British Museum Library er i enhver henseende disse biblioteker overlegent. ${ }^{42}$ Specielt fremhæver Panizzi museumsbibliotekets læsesal og den udstrakte service, der ydes der. Som dokumentation fremlægger han bl.a. et brev fra en amerikaner, der har benyttet bibliotekerne i København, München, Paris, Rom og Wien. Ikke et af disse biblioteker kan måle sig med British Museum's bibliotek, hvor der er adgang til katalogerne, enkle rutiner og hurtig ekspedition. ${ }^{43}$

Efter sin optræden for den kongelige kommission stod Panizzi stærkt, og i 1856 blev han udpeget til Principal Librarian og dermed leder af hele British Museum.

Epilog

1850 var året, hvor kommissionsbetænkningen om British Museum viser Panizzi som den konstruktive kraft i institutionen. Det var året, hvor parlamentet, bl.a. på baggrund af Edwards' agitation, vedtog den lov, der gav kommunerne ret til at opkræve penge til at finansiere offentlige biblioteker. Men det var også året, hvor Edward Edwards endelig blev fyret fra British Museum. Forud var gået lang tids kamp mellem ham og Panizzi. Nok var Edwards et uroligt hoved uden overvældende orden i sine sager, men Panizzis reaktioner over for ham har en sådan karakter, at det ligner forfølgelse. ${ }^{44}$

Edwards flyttede til Manchester, hvor han blev folkebibliotekspioner. Han fortsatte sit arbejde med biblioteksstatistik. Under forberedelsen af loven om offentlige biblioteker var han med til at formulere de spørgsmål, der via udenrigsministeriet sendtes til en række europæiske biblioteker. Også dette materiale blev offentliggjort i udvalgsbetænkningen. ${ }^{45}$

I bearbejdet form indgår det i Edwards' imponerende Memoirs of Libraries including a Handbook of Library Economy (1859), som også har afsnit om københavnske biblioteksforhold. ${ }^{46}$

I sit korte rids af biblioteksstatistikkens historie nævner Georg $L e y h$, at vurderingen af den svinger mellem total afvisning af dens 
værdi og nærmest ukritisk brug. ${ }^{47}$ Både Antonio Panizzi og Edward Edwards arbejdede med statistik og sammenligninger mellem forskellige biblioteker, men deres måde at gøre det på illustrerer den kendsgerning, at tallene i sig selv er mindre interessante. Det afgørende er den sammenhæng, det biblioteksbillede, de sættes ind $i$. Det er det, der giver tallene betydning.

\section{NOTER}

1. Jf. Arundell Esdaile: The British Museum Library. A Short History and Survey (London 1946), s. 90f. - Hos Chr. Molbech kan man spore kritikken. I sin bog Om offentlige Bibliotheker (Kbh. 1829) nævner han kritik af engelske biblioteksforhold (s. 177 n. 107), og han fremhæver de kongelige biblioteker i Paris og Berlin som mønstergyldige (s. 122, n. 76).

2. Oversigterne fra København findes i Report from the Select Committee on the Condition, Management and Affairs of the British Museum; together with the Minutes of Evidence, Appendix and Index, London 1835, i: British Parliamentary Papers. Education, British Museum, 1, s. $482-483$ (Shannon 1968). - En del af materialet indhentet via ambassaderne er trykt i 1836-udvalgets rapport, i: British Parliamentary Papers. Education, British Museum, 2, appendix 10.

3. Panizzis oplysninger er trykt som Appendix 6 i Report from the Select Committee on British Museum, together with the Minutes of Evidence, Appendix and Index, London 1836, i: British Parliamentary Papers. Education, British Museum, 2, s. 542-563 (Shannon 1968).

4. Report from the Select Committee on Public Libraries, together with the Proceedings of the Committee, Minutes of Evidence, Appendix and Index, London 1850, i: British Parliamentary Papers. Education, Public Libraries, 2, s. 51, $§ 715$ (Shannon 1968).

5. Hverken i KB's arkiv eller i Panizzis papirer i British Library findes der noget om henvendelsen til $\mathrm{KB}$.

6. Ud over Universitetsbiblioteket og Det Classenske Bibliotek nævner han Regensens bibliotek, Kirurgisk Akademis bibliotek, Botanisk Haves bibliotek og Athenæum (Report, 1836, s. 542 n. 3). - I oversigten fra 1835 nævnes også stiftsbibliotekerne og et bibliotek i Island (Report, 1835, s. 483).

7. Panizzi anfører med henvisning til den italienske geograf A. Balbi, at antallet af varker i KB skønnes at være 500.000 (mange værker er indbundet sammen). Balbi angiver $i$ sin Hausbuch des geographischen Wissens, I, s. 496 (Güns $1834)$, at $\mathrm{KB}$ er "an Bändezahl die dritte Europas ".

8. Report, 1836 , s. 388, \4774.

9. Report, 1836 , s. $390, \$ 4790$. - I oversigten fra 1835 anføres det, at KB har 4000 
rigsbankdaler til bogkøb, og at 1 pund sterling svarer til 9 rbd. (Report, 1835, s. 483 )

10. E. C. Werlauffs udsigt over Det kongelige Biblioteks tilstand i 1829. Ved Palle Birkelund, i: Nordisk Tidskrift för Bok- och Biblioteksväsen, 43, 1956, s. 13 (bogbevillingen angives her til 4400 rigsbankdaler). Svend Dahl: Adam Wilhelm Hauch som bibliotekschef, i: Fund og Forskning, 2, 1955, s. 22. - I 1830 opfordrer C. Molbech Werlauff til at overskride bevillingerne; hellere fầ en "næse" for at bruge for meget end at bruge for lidt! Fra Det kgl. Bibliotek for hundrede Aar siden. Breve vekslede mellem E. C. Werlauff og C. Molbech. Ved Svend Dahl, i: Nordisk Tidskrift för Bok- och Biblioteksväsen, 31, 1944, s. 9.

11. "Whatever use the public make of them is to be considered rather as a matter of favour than of right " (Report, 1836, s. 543).

12. Report, 1836 , s. 551 og s. 552.

13. Report, 1836 , s. 546.

14. "The indulgence of granting the use of catalogues to the readers depends wholly on the headlibrarian's will " (Report, 1836, s. 548).

15. Report, 1836, s. 559 og s. 560. - Fra januar 1827 var KB's åbningstid kl. 11-14, alle søgnedage. E. C. Werlauff: Historiske Efterretninger om det store kongelige Bibliothek i København, 2. udg., s. 374ff. (Kbh. 1844).

16. Report, 1836, s. 555 og s. 556.

17. Report, 1836, s. 557.

18. Report, 1836 , s. $389, \$ 4780-4781$.

19. Report, 1836 , s. $400, \S 4863$ og s. $401, \S 4870$.

20. Katalogspørgsmålet kom til at give anledning til megen strid både inden for og uden for British Museum Library i de næste 15 år. Om Panizzis rolle kan man læse i Edward Miller: Prince of Librarians. The Life and Times of Antonio Panizzi of the British Museum, kap. 7-10 (London 1988).

21. Report, 1836, s. 396-397, $₫ 4835-4841$.

22. Report, 1836 , s. $390, \S 4785$ og s. $391, \S 4795$.

23. "I want a poor student to have the same means of indulging his learned curiosity, of following his rational pursuits, of consulting the same authorities, of fathoming the most intricate inquiry, as the richest man in the kingdom, as far as books go, and I contend that Government is bound to give him the most liberal and unlimited assistance in this respect " (Report, 1836, s. 391, $\ 4795$ ).

24. Report, 1836, s. 396, \9834; s. 397, \4846; s. 401, \4869.

25. Report, 1836 , s. $406, \ 4929 ;$ s. $407, \ 4933$.

26. Report, 1836 , s. 553 . - Om protesterne mod det nye system, se Miller, anf. arb., s. 135.

27. Report, 1836 , s. 391, $₫ 4794$.

28. Simon Nowell-Smith: Carlyle and the London Library, i E. B. Oldman m.fl.: English Libraries 1800-1850, s. 61 (London 1958). I et offentligt møde forud for 
stiftelsen af London Library fremhæver Carlyle den danske konges interesse for biblioteker: "London has more men and intellect waiting to be developed than any place in the world ever has assembled. Yet there is no place on the civilised earth so ill-supplied with materials for reading for those who are not rich. I have read an account of a Public Library in Iceland, which the King of Denmark founded there. There is not a peasant in Iceland that cannot bring home books to his hut, better than men can in London. Positively it is a kind of disgrace to us, which we ought to assemble and put end to with all convenient despatch. The founding of a Library is one of the greatest things we can do with regard to results. It is one of the quietest of things; but there is nothing that I know of at bottom more important. Every one able to read a good book becomes a wiser man. He becomes a similar centre of light and order, and just insight into the things around him. " Citeret efter C. J. Purnell: The London Library, i Raymond Irwin \& R. Staveley (eds): The Libraries of London, s. 232. London 1961. (Carlyle kan have sit kendskab til biblioteket $\mathrm{i}$ Island fra udvalgsrapporten fra 1835, se note 6).

29. Jf. om Panizzis nationalbiblioteksideal: K. W. Humphreys: A National Library in theory and in practice, kap. 1: The Autarchic Library (Panizzi Lectures, 1987; London 1988).

30. Uefterrettelige lånere, se Svend Dahl: Adam Wilhelm Hauch som bibliotekschef, anf. st., s. 23. Chr. Molbech talte for indskrænkning af udlån, mens E. C. Werlauff stille, men indtrængende, taler for at opretholde den eksisterende praksis. Werlauff peger på, at en indskrænkning kan fâ uberegnelige følger for almindelig oplysning og videnskabelig kultur - og fjerne grundlaget for større bevillinger! - Fra Det kgl. Bibliotek for hundrede Aar siden. Breve vekslede mellem E. C. Werlauff og C. Molbech. Ved Svend Dahl, anf. st., s. 18.

31. W. A. Munford: Edward Edwards 1812-1886. Portrait of a Librarian, s. 18ff. (London 1963). Edwards' vidneudsagn findes i Report, 1836, s. 377-387.

32. Artiklen blev offentliggjort i Journal of the Statistical Society of London, vol. 11, 1848. I bearbejdet form findes materialet i Report from the Select Committee on Public Libraries with the Proceedings of the Committee, Minutes of Evidence, Appendix and Index. London 1849, i: British Parliamentary Papers. Education, Public Libraries, 1, s. 255-293 (Shannon 1968).

33. Om de københavnske biblioteker siger han, at det generelle princip er "to require some sort of introduction, but I believe there is not much difficulty practically in obtaining those introductions « (Report, 1849, s. 6, \80).

34. Report, 1849, s. 217, §3314-3316.

35. Om Panizzis kampagne, Miller, anf. arb., s. 189f., og Munford, anf arb., s. 74.

36. Report from the Select Committee on Public Libraries; together with the Proceedings of the Committee, Minutes of Evidence, Appendix and Index, London 1850, i: British Parliamentary Papers, Education, Public Libraries, 1, s. 52, $\S 719 ;$ s. 546, $₫ 725 f$. 
37. Report, 1850 , s. 70 f., $\int 815 \mathrm{ff}$ - Edwards' svar på kritikken af talmaterialet er trykt som tillæg i udvalgsrapporten, Report 1850, Appendix 1, s. 79-85. Edwards fremhæver, at han snarere har angivet for lave tal for de udenlandske biblioteker end for høje. Han har altså ikke pustet tallene op for på den måde at give et grelt billede af forholdene i Storbritannien.

38. Kendt er hans polemik mod Carlyle, i Report of the Commissioners on the Constitution and Government of the British Museum with Minutes of Evidence and Index, 1850, i: British Parliamentary Papers. Education. British Museum, 3, s. 641f., \$9366ff. (Shannon 1968). Panizzi siger (\$9373): "there is no place like the Museum of the World for equal attention to all readers ".

39. Report, 1850 , s. 59, \740-741; s. 60, \747-748; s. 62, \762, \766.

40. I registret til kommissionsbetænkningen fylder opslagsordet "catalogues " 32 tættrykte spalter!

41. Louis Fagan: The Life of Sir Anthony Panizzi, K. C. B., vol. 1, s. 255 (London 1880).

42. Report of the Commissioners, 1850, s. $617, \S 9167$.

43. Report of the Commissioners, 1850 , s. 264, $₫ 4285$.

44. Miller, der ellers er positiv over for Panizzi, henviser som forklaring til "the vendetta instincts of his race «! (anf. arb., s. 194).

45. Report, 1850, Appendix 2. Om københavnske biblioteker, s. 174-176. Om sin rolle $\mathrm{i}$ indsamling af dette materiale, se Edwards: Memoirs of Libraries, vol. 2, s. 989. London 1859.

46. Se vol. 2, s. 514-524 og s. 994.

47. Georg Leyh: Statistik, i: Franz Milkau (Hrsg.), Handbuch der Bibliothekswissenschaft, Bd. 2, s. 566 (Leipzig 1933). 